Ks. Ryszard GROŃ

(PWT, Wrocław)

\title{
ŚMIERĆ AELREDA Z RIEVAULX - MIĘDZY TEORIĄ A RZECZYWISTOŚCIĄ
}

Śmierć Aelreda, słynnego średniowiecznego opata z angielskiego opactwa cysterskiego Rievaulx, została opisana przez jego bliskiego współpracownika, sekretarza Waltera Daniela, mnicha, który znał Aelreda najlepiej, szczególnie w ostatnim etapie jego życia. Jemu też przyszło opiekować się opatem podczas choroby, która bezpośrednio poprzedziła samą śmierć, której też niewątpliwie musiał być naocznym świadkiem. Jest to jedyny opis śmierci Aelreda, jaki został utrwalony, i jako taki stanowi dziś fundament podstawowej wiedzy na ten temat. Oczywiście, należy go odczytać na tle swoistego rodzaju literackiego, w jakim został spisany, wraz ze wszystkimi możliwymi uwarunkowaniami, płynącymi zarówno od autora, jak i od odbiorców, do których był skierowany; wreszcie trzeba uwzględnić obowiązujące wówczas zwyczaje i ryty liturgiczne, które dopiero wtedy pozwolą uchwycić rzeczywistość tej śmierci, wyciągając ją z jej literackiej szaty i odczytując jej ewentualnie ukryte intencje.

Relacja o śmierci opata Aelreda stanowi ostatnią część utworu Waltera Daniela Vita Aelredi, należącego do rodzaju hagiografii, powszechnie uprawianego wówczas gatunku literackiego ${ }^{1}$. Celem pisarstwa hagiograficznego było krzewienie ideału świętości, przywołującego żywoty znaczących osób z ówczesnego życia społecznego, takich jak: królów, królowych, książąt, opatów, opatek, biskupów, baronów, których przykłady życia miały służyć jako swoiste moralno-religijne zwierciadło, chrześcijański wzór postępowania. Czasem były to postaci z odległej historii, przywoływane dla aktualnych potrzeb z różnych okazji. Model świętości był wzorowany na ideale życia mniszego z otoczenia, w którym powstawały utwory, głównie benedyktyńskiego i cysterskiego. Chodziło o życie w ubóstwie, miłości i czystości, wzór tzw. świętego wyznawcy,

* Referat wygłoszony na 42. Międzynarodowym Kongresie Studiów Mediewistycznych, jaki miał miejsce w Kalamazoo Mi (USA), w dniach 10-13 maja 2007 roku.

${ }^{1}$ Por. W. Danielis, Vita Ailredi abbatis Rievall', ed. M.F. Powicke, Oxford 1950 (Oxford University Press 1978) (dalej: Vita Ailredi); por. Powicke, Introduction, w: W. Danielis, Vita Ailredi abbatis Rievall', s. LXXVI 
ucieleśniony w bardzo popularnym wówczas żywocie św. Marcina z Tours z czwartego wieku, autorstwa Sulpicjusza Sewera.

Ostatnim elementem hagiograficznego życiorysu był opis śmierci, który jawił się tu nie tylko jako chwalebne zwieńczenie całego cnotliwego życia danej osoby, ale przede wszystkim jako przykład „dobrej śmierci”, stanowiąc tym samym zwierciadło chrześcijańskiego sposobu umierania. Chodziło o śmierć spokojną, jako efekt życia zgodnego z panującym ideałem; śmierć przygotowaną szczególnie w jej ostatnim etapie poprzez przyjęcie przepisanych nauką i tradycją Kościoła modlitw, zwyczajów i rytów, jednoczących umierającego z Bogiem i ludźmi, tak by jego dusza - jak uczy wielki reformator cysterski św. Bernard z Clairvaux - mogła spokojnie „przejść” (migrare) z tego świata i „spocząć” (quiescere) lub „zasnąć” (somniare) w bezpiecznych ramionach Boga. Nazywano ją za Bernardem ,śmiercią wspaniałą” (mors preciosa) lub „śmiercią świętą” (mors sancta) ${ }^{2}$, co we współczesnym języku proponuje się oddać przez pojęcie „śmierci obłaskawionej” (tame death) ${ }^{3}$.

Opisy tego rodzaju śmierci odzwierciedlały zapewne panujące wówczas zwyczaje, zawierając kilkanaście podstawowych elementów ${ }^{4}$ :

- przeczuwanie śmierci i powiadomienie o niej otoczenia (A),

- uporządkowanie spraw doczesnych i wyrażenie ostatniej woli (B),

- udzielenie sakramentów Kościoła: Spowiedź, Eucharystia podczas Mszy św. lub wiatyk poza nią, Namaszczenie Chorych (C),

- modlitwy pokutne psalmami,

- kontemplacja krzyża i/lub czytanie opisu Męki Pańskiej (D),

- litania do Wszystkich Świętych w przypadku przedłużającej się agonii,

- ułożenie umierającego na włosienicy posypanej popiołem (E),

- modlitwy w intencji zmarłego: oficjum brewiarzowe (F),

- umycie i balsamowanie ciała po zgonie $(\mathrm{G})$,

- Msza pogrzebowa i rozdawanie jałmużny ubogim $(\mathrm{H})$,

- pochówek z towarzyszącym konduktem pogrzebowym (I),

- Msze św. za zmarłego w ciągu miesiąca oraz towarzyszące temu rozdawanie biednym jałmużny ${ }^{5}$.

2 Por. J. Leclercq, The joy of dying according to St. Bernard, „Cistercian Studies Quarterly” 25 (1990) 163-174; B. Pranger, The concept of death in Bernard's „Sermons on the Song of Songs”, w: J.R. Sommerfeldt (red.), Bernardus magister. Papers presented at the nonacentenary celebration of the birth of Saint Bernard of Clairvaux, Kalamazoo 1992, 85-93; przeciwwagą tego rodzaju świętego umierania miała być „śmierć nieoczekiwana” (mors improvisa) - nagła, nieprzygotowana, tzn. bez możliwości pojednania, więc w grzechu i trwodze konania jako antycypacja wiecznego potępienia.

${ }^{3}$ Por. P. Aries, The hour of our death, New York - Oxford 1981, 5-22.

${ }^{4}$ W wykazie wyszczególnione zostały wszystkie elementy, na które składa się model „dobrej śmierci”, sporządzone na podstawie badań F.S. Paxton w zestawieniu z tradycją cysterską (zob. przyp. 5); w nawiasach podano punkty występujące jedynie w opisie Daniela Waltera, które szczegółowo będą omawiane w następnej partii artykułu.

${ }^{5}$ Por. F.S. Paxton, Liturgy and anthropology. A monastic death ritual of the eleventh century, 
Do tego podstawowego schematu z reguły dochodziły jeszcze elementy cudownej scenerii, właściwe piśmiennictwu hagiograficznemu, zaczerpnięte z żywota św. Marcina, jak: wizja prorocza dotycząca momentu własnej śmierci (J), jaśniejące blaskiem oblicze i ciało zmarłego (K), nierzadko cuda nad jego grobem (L) ${ }^{6}$. Miały one na celu potwierdzić niejako ,z góry” (od Boga) wyjątkowo cnotliwe życie zmarłego, które złożyło się na jego świętość, przydając tej śmierci nowej teologicznej jakości. Sulpicjusz Sewer w swym opisie śmierci św. Marcina nazywa ją wprost śmiercią męczeńską, właśnie z racji heroicznego życia w miłości i czystości ${ }^{7}$, co w późniejszej tradycji zaczęła symbolizować woń kwiatów: róży i lilii.

Do elementów hagiograficznego opisu należy także zaliczyć klimat pewnej przedśmiertnej dramaturgii, jaka się rozgrywała między umierającym a jego bliskim otoczeniem, również wzorowany na opisie śmierci św. Marcina. Otoczenie umierającego pogrążało się w smutku, kiedy dochodziła do niego informacja o zbliżającej się śmierci ich bohatera w przeciwieństwie do samego zainteresowanego, który z radością wyczekiwał utęsknionego spotkania z Bogiem (M) ${ }^{8}$.

Aelred z Rievaulx znał ten model „,dobrej śmierci” i nieraz opisywał go w swoich utworach historycznych ${ }^{9}$. Teraz on sam, dzięki swemu sekretarzowi, stał się przykładem podobnego umierania. Walter zawarł je we wspomnianym wyżej utworze, napisanym pewnie (lub ostatecznie zredagowanym) zaraz po śmierci swego bohatera ${ }^{10}, \mathrm{w}$ formie bliskiej lamentacji. W opisie można wyraźnie uchwycić większość elementów wspomnianego modelu (A-I), które poza specyfiką hagiograficznych wymogów (J-M) niewątpliwie odzwierciedlają prawdziwy przebieg śmierci opata. Relacja Waltera Daniela jako naocznego świadka tej śmierci przydaje tu dodatkowego argumentu uwierzytelniającego.

1. Przebieg śmierci Aelreda. Śmierć Aelreda z Rievaulx jest faktem niezaprzeczalnym, jak niepodważalnym było jego historyczne istnienie. Jak zauważa autor żywota, Daniel, została ona poprzedzona chorobą opata, która doprowa-

Missoula 1993, 7-14; tenże, A medieval Latin death ritual: The monastic customeries of Bernard and Urlich of Cluny, Missoula 1993; por. cysterskie elementy związane ze śmiercią mnicha: Ecclesiastica officia 93-94; D. Choisselet - P. Vernet (red.), Les ecclesiastica officia cisterciens du XII ${ }^{\text {ème }}$ siècle, Reiningue 1989, 267-276.

${ }^{6}$ Por. Sulpicius Severus, Epistola 3, 6. 9-21, PL 20, 181-184, thum. P. Nowak, ŹM 8, 101-105.

7 Por. Epistola 2, PL 20, 179-180, ŹM 8, 95-99.

${ }^{8}$ Por. Epistola 3, 17, PL 20, 182-184, ŹM 8, 104

${ }^{9}$ Por. Vita Sancti Niniani 2, 11 (Pinkerton's Lives of the Scottish Saints, Paislay 1889, 34-36); Vita Sancti Eduardi Confessoris, PL 771-776; Lamentatio Davidi Scotorum regis 10-12, ed. Pinkerton's Lives, s. 280-285; szerzej na ten temat, zob. R. Groń, Examples of 'good death' in Aelred of Rievaulx, „Cistercian Studies Quarterly” 41 (2006) 421-441; tenże, Przykłady „,dobrej śmierci" u Aelreda z Rievaulx, VoxP 25 (2205) t. 48, 292-312.

${ }^{10}$ Por. M.L. Dutton, Introduction to Walter Daniel's 'Vita Aelredi', w: W. Daniel, The Life of Aelred of Rievaulx and the Letter to Maurice, Kalamazoo 1994, 75-79. 
dziła ostatecznie do jego zgonu ${ }^{11}$. Na podstawie jego opisu ${ }^{12}$ i w zestawieniu z ówczesnymi zwyczajami związanymi z modelem ,dobrej śmierci”, można ustalić dość dokładnie przebieg tego umierania, a także dzień i przybliżoną godzinę śmierci opata.

(A) Na kilka dni przed śmiercią dało się zauważyć wyraźne osłabienie fizyczne i cierpienie Aelreda z powodu daleko posuniętych zmian chorobowych. Daniel drobiazgowo opisuje blade oblicze opata, jego pocenie się i wycieńczenie przy najmniejszym wysiłku, jaki wykonywał, tak, że np. po Mszy św. i modlitwach popołudniowych w kaplicy (Nieszporach) musiał być zaniesiony do swej celi na rękach usługujących braci i minęło około dwóch godzin zanim doszedł do siebie. Z dnia na dzień stawał się coraz słabszy, aż wreszcie 3 stycznia (1167 r.), przeczuwając swój bliski koniec (in articulo mortem), nakazał mnichom, by się zgromadzili przy nim, kierując do nich słowa ostatniego pożegnania ${ }^{13}$.

(B) Po tym pożegnaniu poprosił o swój Psałterz, ulubione Wyznania Augustyna, tekst Ewangelii Jana oraz relikwie biskupa Henryka Murdaka i wyrażając swą ostatnią wolę oddał to wszystko braciom. Podał również wskazówki, co do wyboru następcy i przestrzegania reguły Benedykta oraz udzielił im swego błogosławieństwa, tak wyczekując błogosławieństwa Bożego ${ }^{14}$.

(C) Następnego dnia (5 stycznia) został namaszczony świętymi olejami przez Rogera, opata z Byland i umocniony wiatykiem najświętszego misterium Ciała i Krwi Pańskiej. Po tym pokarmie już nic nie zjadł do samej śmierci ${ }^{15}$.

(D) Następnej nocy jego stan tak się pogorszył, że zaczął gubić się w mowie, wypowiadając jedynie krótkie urwane słowa. Powtarzał przy tym łatwiejsze do wypowiedzenia słowa angielskie przynaglające do szybszej śmierci (,szybciej, na miłość Chrystusa”); i tak było przez trzy dni ${ }^{16}$. Dzień przed śmiercią zebrała się w jego celi niemal cała wspólnota braci wraz z dwoma asystującymi opatami (wspomnianym już Rogerem oraz Ryszardem z Fountains) i odczytano tekst

${ }^{11}$ Przejawy tej choroby opisane przez Daniela Vita Ailredi 48-49, ed. Powicke, s. 54-56) wskazują na połączenie kamicy nerkowej i artretyzmu (por. A. Squire, Aelred of Rievaulx. A study, London 1981, 129) i „,być może półpaśćca” (Dutton, Introduction, s. 36).

12 Por. Vita Ailredi, 49-60, ed. Powicke, s. 56-64.

13 Por, tamze 49-50, ed. Powicke, s. 56-58, spec. 49, s. 57: „Et de die in diem corpus illius debilitabatur in tantum ut iij (sic!) Nonas Januarii iusserit ante se vocari omnes monachos".

${ }^{14}$ Por. tamże 51, ed. Powicke s. 58: „Post hec precepit afferri coram se psalterium glosatum et confessiones Augustini et textum evangelii Johannis et reliquias quorundam sanctorum et parvulam crucem que fuerat bone memoriae archiepiscopi Henrici Eboracensis, et dixit nobis, «[...] unde non facio testamentum, quia nihil possideo proprium, vestrum est quicquid habeo et ego ipse». Admonuit nos etiam ut in eleccione successoris eius quereremus non que nostra sunt sed que sunt Dei [...]. Deinde dedit omnibus paternam benedictionem et optavit divinam”.

15 Por. tamze 52, ed. Powicke, s. 59: „Die vero altera oleo sanctificationis perlinitur a Rogero venerabili abate de Beilandia et viatico munitur misterii sacrosancti dominici Corporis et Sanguinis [...]. Nullus tamen masticabilis cibus in os eius insumitur a die $\mathrm{x}$-mo usque ad obitum".

16 Por. tamże 53-54, ed. Powicke, s. 59-60. 
Męki Pańskiej, którą umierający słuchał, reagując na zmiany poszczególnych akcji ${ }^{17}$. Później obecny tam Daniel pomógł mu adorować krzyż; podczas tej adoracji miały już tylko paść ostatnie słowa opata: „W ręce Twoje powierzam ducha mego"; umierający opat przeleżał do „czwartego nocnego czuwania” (ad quartam vigiliam), kiedy to nastąpiła śmierć ${ }^{18}$.

(E) Kiedy zorientowano się, że śmierć jest już bardzo blisko, ułożono opata według zwyczaju na włosienicy posypanej popiołem ${ }^{19}$.

(F) Następnie czterech opatów wraz z braćmi odmówiło zapewne modlitwy w intencji opata, podczas gdy on sam powierzył się Bogu ${ }^{20}$. I tak umarł „około czwartego czuwania nocnego", według dawnego zwyczaju liczenia czasu, „przed Idami stycznia, w roku od Wcielenia 1066, który był pięćdziesiątym siódmym rokiem jego życia"; co w przeliczeniu na współczesne realia, przy uwzględnieniu starego kalendarza, jakim posługiwał się autor, daje dzień 12 stycznia 1167 r., godz. ok. 10.30 wieczorem $^{21}$.

(G) Daniel umieścił długą dygresję o zwyczajowym obmyciu ciała opata (które nazwał chrztem), o całowaniu przez niego jego stóp, jako wyrazie swej miłości i przywiązania, wreszcie o namaszczeniu ciała balsamem przez Rogera z Byland ${ }^{22}$.

(H) Po wszystkim, ciało Aelreda zostało złożone w kościele, gdzie odprawiono Msze św. oraz pozostałe ryty pogrzebowe ${ }^{23}$.

17 Por. tamże 56, ed. Powicke, s. 60-61

18 Por. tamże 56-57, ed. Powicke, s. 61-62: „Pridie sane quam obiret, abbas de Fontibus et abbas de Beilandia Rogerus assistebant illi et pene omnes monachi et non nulli conversi. Legebat autem quidam frater passionem Domini, illo audiente, qui verba iam formare non valebat ut intelligerentur [...]. In illo die sedi ego et sustentavi caput eius minibus meis, aliis longius consedentibus nobis. Dixi autem demissa voce, nemine nobis intendente. «Domine respice ad crucem et ibi sit oculus tuus ubi etiam cor». Statim ergo palpebras elevans et pupillas luminum porrigens ad figuram veritatis depictam in lingo, dixit ad illum qui pro nobis in lingo pertulit mortem, «Tu es Deus meus et Dominus meus, tu refugium meum et Salvator meus, tu gloria mea et spes mea in eternum. In manus tuas commendo spiritum meum»".

19 Por. tamże 57, ed. Powicke, s. 62: „At tunc nobis eum iam iamque obiturum sentientibus, positus est super cilicium et cinerem more monachorum".

${ }^{20}$ Por. tamże 57, ed. Powicke, s. 62: „Filiorumque turba circa illum adunata cum abbatibus quattuor qui affuerant, in manus Patris inpollutum spiritum emittens, quievit in Christo".

${ }^{21}$ Por. tamże: „Obiit autem circa quartam vigiliam noctis pridie Idus Januarii, dominicae videlicet incarnationis anno millesimo $\mathrm{c}(\mathrm{o}) \mathrm{lx}(\mathrm{mo})$ vi(to), qui fuit annus vitae illus quinquagesimus septimus"; zob. Powicke, s. 62, nota 1; Dutton, Introduction, s. 38 wraz z przypisem 50; należałoby tu wspomnieć o odmawianej modlitwie brewiarzowej za zmarłego, której tu nie wymieniono pewnie ze względu na tradycyjną oczywistość mającą miejsce w klasztorach.

22 Por. tamże 58-59, ed. Powicke, s. 62-64, spec. 59, s. 63: „Corpus eius ad lavandum/delatum fuisset et mudatum coram nobis [...]; corpus eius pro consuetudine, non pro necessitate, baptizatum fuisset $[\ldots]$, in vasculo quodam parum balsami attulit quidam ad nos, quod ipse pater habuerat ad medicinam. Hoc ergo liquore, immo guttula liquoris huius [...], (abba Rogerus) patris faciem inunxit, frontem aures et collum oculos et nasum totumque caput, [...] manus patris [...] ungere".

${ }^{23}$ Por. tamże 60, ed. Powicke, s. 64: „Post que delatum est corpus eius in oratorium et in crastino, missis celebratis et debitis circa patris exequias obsequiis exhibitis et consummates". 
(I) Pogrzebano je później w kaplicy zakonnej obok jego świątobliwego poprzednika Williama ${ }^{24}$.

2. Hagiograficzne elementy opisu śmierci Aelreda. Opis śmierci Aelreda przedstawiony powyżej, jest zapewne odzwierciedleniem prawdziwego przebiegu jego śmierci, jednak będąc częścią dzieła hagiograficznego, jest już jego hagiograficzną interpretacją. Został on bowiem napisany w określonych warunkach, w obliczu pewnego wyzwania, o czym świadczy wewnętrzna krytyka utworu oraz dodatkowy list Daniela do niejakiego mnicha Maurycego (być może przeora z Kirkham ${ }^{25}$, w którym autor usprawiedliwia swój punkt widzenia zawarty w utworze.

Przede wszystkim zastanawia badaczy niemal zupełny brak w Żywocie Aelreda wzmianek o publicznym zaangażowaniu opata w sprawy społecznopolityczne poza opactwem, znanym z innych źródeł. Okazuje się, że dzieło Daniela miało ten brak celowo ukryć, aby uwypuklić bardziej duchowy monastyczny aspekt działalności swego bohatera w ramach życia klasztornego, dzięki czemu można go było wykreować na świętego opata ${ }^{26}$. Z jednej strony jest to poniekąd usprawiedliwione, jako że sam utwór powstawał w ostatnich latach życia Aelreda, który złożony chorobą rzeczywiście przebywał częściej w klasztorze. Z drugiej jednak strony należało odeprzeć zarzuty części środowiska monastycznego o zbyt ambitnym i świeckim trybie życia, jaki miał prowadzić w ciągu swych długich rządów opactwem, z racji licznych wyjazdów w sprawach kościelno-państwowych. Utwór zdaje się stawiać czoła temu wyzwaniu, próbując ukazać Aelreda jako świętego opata cysterskiego, kontemplatyka i zatroskanego wychowawcę powierzonych jego pieczy mnichów. Dlatego Daniel akcentuje w nim mądrość, pokorę, cierpliwość, miłość oraz moc ducha, jako te elementy, które złożyły się na świętość w ujęciu cysterskim, podbudowując je dodatkowo licznymi cudami ${ }^{27}$. Z tego też powodu sam utwór przybrał tradycyjną formę hagiograficzną, jako tę, która nie tyle interesuje się historycznym biegiem wydarzeń z życia opata ${ }^{28}$, ile przedstawia jego portret charakteryzujący się „miłością i zadziwiającą świętością"29.

List Daniela do Maurycego, napisany pewnie zaraz po właściwym utworze, ukazuje intencje autora i usprawiedliwia stosowane przez niego literackie

${ }^{24}$ Por. tamże 60, ed. Powicke, s. 64: „In capitulo traditur seputure iuxta preecessorem suum virum venerabilem et sanctum primumque abbatem Rieval Willelmum".

25 Por. Epistola ad Mauricium, ed. Powicke, s. 66-81; tenże, Introduction, s. XXIX-XXXI; Dutton, Introduction, s. 66-67 i s. 171 , nota 1.

26 Por. Vita Ailredi 1, ed. Powicke, s. 1 -2.

27 Szerzej na ten temat, zob. Dutton, s. 75-86.

28 Mało w nim informacji na temat dzieciństwa Aelreda, jego pobytu na dworze królewskim, rodziny itp.

${ }^{29}$ Vita Ailredi 1, ed. Powicke, s. 1. 
środki wyrazu, typowe dla dzieł hagiograficznych. Wszystko po to, aby w odpowiedzi na zarzuty przeciwników świętości Aelreda przedstawić go właśnie jako człowieka świętego, na wzór cysterski ${ }^{30}$, którego cnotliwe i pobożne życie zostało zwieńczone ,wspaniałą” śmiercią modelowaną na modłę innych świętych śmierci.

$\mathrm{Za}$ modelem takiej śmierci przemawia przede wszystkim stosowane tu słownictwo. Walter nazywa śmierć Aelreda bernardyńskim „przejściem” (migratio) z tego świata do Ojca ${ }^{31}$; mówi o jego „oddaniu się w ręce Ojca” i „spoczynku w Chrystusie”. Ciało zmarłego wyglądało, jakby opat nie umarł, ale jakby spał ${ }^{32}$.

Jak można było już zauważyć wyżej, opis śmierci opata nawiązuje do tradycyjnego modelu, charakterystycznego dla „dobrej śmierci”. Daniel dodaje doń elementy cudownej scenerii właściwe utworom hagiograficznym, zaczerpnięte z klasycznego opisu śmierci św. Marcina: przepowiednię śmierci przez samego bohatera (J), jaśniejące chwałą oblicze i ciało po jego śmierci (K), oraz cuda zdziałane za jego pośrednictwem, mające wprawdzie miejsce nie nad grobem, jak to jest w pierwowzorze, ale jeszcze za życia opata (L). Wszystkie te trzy elementy miały jakby potwierdzać z góry (ze strony Boga) świętość zmarłego. Daje się tu również zauważyć typowo Marcinową przedśmiertną dramaturgię, jaka się rozgrywała między umierającym i jego uczniami, czyli mnichami z Rievaulx (M).

(J) Na trzy dni przed śmiercią Aelreda, siły fizyczne tak go już opuściły, że ledwo oddychał i nie był w stanie wypowiadać słów, choć jego duch był cały czas mocny. Wtedy jeden z braci, który z reguły opiekował się chorym, kiedy zmęczony spał w przyległym pokoju, nagle ujrzał opata, który w rozmowie przepowiedział mu dzień swego odejścia z tego świata, tj. „,w dzień przez Idami stycznia”, co się później dokładnie spełniło ${ }^{33}$. Nieco wcześniej autor zaznacza, że Aelred rozmawiał z aniołami o swoim odejściu, niejako przynaglając do tego Chrystusa $^{34}$.

(K) Po śmierci opata Daniel zauważa, że jego oblicze i całe ciało przygotowane do mycia, jaśniało niezwykłym blaskiem i pachniało niczym wonnym kadzidłem, ukazując jego przyszłą chwałę; było ono:

${ }^{30}$ Por. Epistola ad Mauricium., ed. Powicke, s. 70, 76, 78, 80.

${ }^{31}$ Por. Vita Ailredi 55 i 52, ed. Powicke, s. 60 i 59; Epistola ad Mauricium., ed. Powicke, s. 74.

32 Por. Vita Ailredi 58, ed. Powicke, s. 62

33 Por. tamże 54-55, ed. Powicke, s. 60.

${ }^{34}$ Por. tamże 54-55, ed. Powicke, s. 59-60: „Angeli confabulantur cum eo, sed illo solo audiente quibus ni fallor sine intermissione respondebat. Hoc enim iugiter ex ore illius sonuit in aures nostras, «Festinate, festinate» [...]. Eodem tempore quidam ex sociis nostris, unus videlicet ex servitoribus patris, resupinus dormitabat pre tedio et ecce pater illi apparens, ut erat infirmus, dixit: «Quando, frater, putas transibo»?. Ad quem ille: «Domine, nescio»; et pater: «Pride Idus Januarii migrabit ancilla Domini anima mea a domo sua terrene quam hucusque inhabitavit». Quod ita evenit ut dormienti fratri pater predixerat". 
„,czystsze niż szkło, bielsze niż śnieg, jakby ciało pięcioletniego dziecka, bez śladu skazy [...]. Doskonały w każdej swej części, zmarły opat świecił jak granat, czysty i nieskalany w jasności swego ciała jak dziecko"35.

(L) Właściwie brak jest cudu nad grobem opata, choć niektórzy badacze mówią o pewnej jego antycypacji w chwalebnej wizji Aelreda przed śmiercią, jaką otrzymał jeden z mnichów ${ }^{36}$. Ponadto Daniel podaje wiele cudów zdziałanych za wstawiennictwem Aelreda, mających jednak miejsce jeszcze za jego życia, co wskazuje na ich określone znaczenie. Podobnie jak jego pozostałe osiągnięcia życiowe, miały one służyć potwierdzeniu raczej cnotliwego życia Aelreda w miłości i pokorze, niż nadprzyrodzonej siły, jaką miałby się odznaczać za życia czy po śmierci. Wskazuje na to wiązanie tych cudów z praktyką miłości Aelreda, stosunkowo mało nadzwyczajny ich charakter oraz nieustanne podkreślanie przez autora, że największym cudem, jakim się opat odznaczał, były właśnie praktykowane przez niego pokora i miłość ${ }^{37}$.

Największa działalność cudotwórcza Aelreda (proroctwa, odwiedziny aniołów, walka $z$ szatanem, odczytywanie myśli) ${ }^{38}$ przypada jednak na ostatnie cztery lata jego schorowanego i naznaczonego cierpieniem życia, niejako na znak potwierdzenia ze strony nieba jego świętości. Temu świadectwu miała służyć zapewne wspomniana wcześniej wizja pewnego mnicha oglądającego swego opata bliskiego śmierci w jasnej chwale, chcąc pokazać niejako błogosławiony stan jego duszy ${ }^{39}$.

W relacji Daniela, brat ów zobaczył nad leżącym na łożu w bezruchu opatem jasną poświatę, która - jak później wyjaśnił mu anioł - reprezentowała jego duszę:

„Była ona w formie człowieka jaśniejącego blaskiem większym niż blask słońca, jaśniejsza niż cokolwiek ludzkie oko może zobaczyć na tym świecie, tak czysta i jasna, tak bez żadnego cienia promieniowała w pełni swego blasku, (iż) cały budynek jaśniał z tej figury, [...] niczym jasność z tysiąca świec"

35 Tamże 58, ed. Powicke, s. 62: „Cum autem corpus eius ad lavandum delatum fuisset et nudatum coram nobis, vidimus quodamodo futuram gloriam revelatam in patre, cuius caro vitro purior, nive candidior, quasi quinquennis pueri membra induerat, que ne parue quidem macule nevus fuscabat, set errant omnia plena dulcedinis decoris et delectacionis [...]; integerrimis partibus corporis existentibus, lucebat pater defunctus ut carbunculus, ut thus redolebat, apparebat in candore carnis ut puerulus purus et inmaculatus".

36 Por. Vita Ailredi 54.

${ }^{37}$ Por. Epistola ad Mauricium, ed. Powicke, s. 78-81; zob. Dutton, Introduction, s. 58-67 i 74.

38 Por. Vita Ailredi 43-45, ed. Powicke, s. 50-51.

39 Por. tamże 47, ed. Powicke, s. 52-54.

40 Tamże 47, ed. Powicke, s. 53: „(Frater) levans oculos ad tectum domus vidit imaginem hominis relucentem super claritatem solis et super omne quod carnalibus oculis in hoc mundo, que utique tam pura et tam lucida et tam sine omni obscuritate in omni autem claritatis plenitudine rutilabat, ut sicut in radio solis arbores vel parietes quid cernimus splendescere, sit totum illud 
Postać ta unosiła się w powietrzu niczym kula świecąca w obłoku, nie podtrzymywana, ani z góry ani z dołu, za wyjątkiem ledwo dostrzegalnej cieniutkiej chmurki w okolicach pępka, do której wydała się być przymocowana. W rozmowie $\mathrm{z}$ aniołem mnich dowiedział się, że tak jaśnieją dusze sprawiedliwych, a cienka chmurka u pępka jest tym, czego opatowi jeszcze brakuje do całkowitej świętości, by zamienić się w światło; wtedy będzie mógł być zabrany do królestwa Ojca. Po skończonej wizji brat z radości obcowania z tak świętym opatem zaczął krzyczeć, budząc tym pozostałych mnichów ${ }^{41}$.

(M) Ostatnim elementem hagiograficznego opisu śmierci Aelreda jest Marcinowa atmosfera, jaka panowała w klasztorze w trakcie umierania opata. On sam z utęsknieniem wyczekiwał momentu swego odejścia, niemal przynaglając Jezusa do tego, tym bardziej, że cierpiał fizycznie; ku ogólnemu smutkowi mnichów, którzy - wprawdzie radowali się z jego bliskiej chwały - boleli jednak nad odejściem swego świętego ojca, ponieważ zdawali sobie sprawę, że zostaną już bez jego opieki i kierownictwa. Widać to szczególnie wyraźnie w mowach pożegnalnych opata ze swymi mnichami i w reakcjach wybuchu płaczu tych ostatnich ${ }^{42}$.

Nie wszystkie wspomniane elementy hagiograficznej ekspresji musiały być zaraz fantastyczne. Na przykład ostatni element wyrażający wzajemne uczucia obydwu stron sceny umierania, mógł mieć miejsce w rzeczywistości, tym bardziej, że Aelred cierpiał fizycznie już dłuższy czas, więc mógł pragnąć skrócenia swego cierpienia; z drugiej strony, mnisi rzeczywiście się smucili z jego odejścia. Dlaczego też nie uznać za realistyczną radość umierającego opata ze zbliżającego się spotkania z Bogiem, któremu przecież całe życie tak wiernie służył?

Pozostałe elementy wydają się mieć charakter bardziej fantastyczny i z reguły były przywoływane w przypadku spisywania żywotów świętych z dalszych epok historycznych, jako tradycyjna, typowo hagiograficzna forma potwierdzenia ich świętości, czerpiąc przy tym z utartych wzorców (tu: św. Marcina). Nieczęsto zdarzało się, by stosowano je w przypadku kogoś współczesnego. Pozwolił sobie na to np. św. Bernard z Clairvaux, który jako naoczny świadek opisał śmierć swego przyjaciela św. Malachiasza, biskupa z Irlandii, ponieważ świętość tego zmarłego nie podlegała dyskusji, a w dodatku była poparta świadectwem samego świętego ${ }^{43}$. Natomiast Aelred z Rievaulx, który prawdopodobnie był obecny przy śmierci swego opiekuna króla Dawida Szkockiego, i ją opisał, nigdy nie podał żadnego z tych elementów, ze względu

edificium lumine illius figure resplenduerit et tanquem mille luminaribus illuminatum emicuerit et refulserit".

${ }^{41}$ Por. tamże 47, ed. Powicke, s. 53-54.

42 Por. tamże 48 i 50, ed. Powicke, s. 55-58.

43 Por. Vita Ailredi Sancti Malachiae episcopi, w: Sancti Bernardi Opera, ed. J. Leclerq - H.M. Rochais, vol. 3, Roma 1963, (ang.: The life and death of Saint Malachy the Irishmen, Kalamazoo 1978). 
na ogólnie znany problematyczny charakter świętości władcy ${ }^{44}$. Daniel, z kolei, który był przekonany o świętości opata z Rievaulx, nie zawahał się użyć wspomnianych elementów hagiograficznych w swej relacji o jego śmierci, dając ich rzadko spotykane wyjaśnienie, które rzuca w ogóle światło na rozumienie rzeczywistości w ujęciu hagiograficznym.

3. Interpretacja opisu śmierci Aelreda przez Waltera Daniela. W relacji śmierci Aelreda można znaleźć rzadko spotykane wytłumaczenie zastosowania elementów hagiograficznych. W obliczu ataku dwóch prałatów na opisaną przez Daniela świętość opata, autor odkrywa swoje karty i pokazuje metodę, jaką zastosował dla oddania przeżywanej przez siebie i współbraci prawdy o śmierci swego ukochanego mistrza, w którego świętość ani przez chwilę nie wątpił. A uczynił to posługując się właśnie elementami z pogranicza cudowności, wskazując nie tylko na ich źródło, ale na stosowane z reguły w utworach hagiograficznych literackie (retoryczne) środki wyrazu, które najlepiej tę prawdę oddają. Chodzi o posłużenie się opisem śmierci św. Marcina z Tours, a szczególnie o jaśniejące blaskiem ciało po jego śmierci, które wydawało woń milszą od kadzidła; oraz o retoryczną hiperbolę (superlatio), której Daniel podał nawet definicję, określając tym samym otwarcie charakter omawianej rzeczywistości. Warto przytoczyć tu fragment z jego Listu do Maurycego, by mieć przed oczyma całą argumentację Daniela:

\begin{abstract}
„Hiperbola [...] jest formą mówienia, która przewyższa prawdę w celu stworzenia czegoś większego lub mniejszego. Przez ten i inne kolory matka mądrość posługuje się swoją zręcznością w obrazie elokwencji (wymowy). Pogański pisarz, który powiedzial: 'mowa słodsza od miodu wypływała z jego ust', jest dobrym tego przykładem. Z kolei w naszych (świętych) księgach: «bystrzejszy od orła, mocniejszy od lwa» (2Sm 1,23). Lub znów w Życiu św. Marcina: «czystszy od szkła, bielszy od mleka» [...]. To nie są nadzwyczajne wyrażenia, ale wprost przeciwnie, są one jak najbardziej na miejscu. Podkreślają wielkie rzeczy, a denerwują głupich krytyków. Po cóż są fakty? Czyż nie powinno się założyć, że ciało zmarłego Aelreda jaśniało, kiedy było myte? To było światło dla nas wszystkich, którzyśmy stali przy nim. I to jakie? O wiele większe niż granat (carbunculus) mógłby dać, gdyby tam był. A ten jego (ciała) aromat wydawał nam się, iż przewyższał zapach kadzidła; wszyscy mieliśmy takie wrażenie. I nic dziwnego; ponieważ nigdy wcześniej w życiu ten tak piękny i przyzwoity człowiek nie był tak jasny na ciele, jak właśnie wtedy, kiedy leżał umarły. Mówię bez żadnego cienia fałszu, że nigdy nie widziałem tak jasnego blasku w żadnym człowieku, czy to żywym, czy umarłym. Musisz mi, więc, wybaczyć, jeżeli wyolbrzymiam to, co jest nieporównywalne, jak na to zasługuje, poprzez zastosowanie dozwolonej hiperboli. Jeżeli tego nie zrobisz, eksperci retoryki publicznie zbesztają twoją głupotę,"45.
\end{abstract}

44 Szerzej na ten temat, por. Groń, Examples, s. 434-441; tenże, Przykłady, s. 305-310.

45 Epistola ad Mauricium, ed. Powicke, s. 77: „Superlacio est oracio superans veritatem alicuius augendi minuendive causa. Hoc colore mater sapientia in pictura eloquentie cum ceteris 
Lektura powyższego tekstu wyjaśnia prawie wszystko. Daniel opisując blask bijący z ciała zmarłego opata, wcale nie zmyślał ani fantazjował, ale wyraził językiem retoryki to, co jest niewyrażalne żadną inną formą, a co działo się w sercu jego i współbraci w chwili mycia ciała zmarłego Aelreda. Wydarzenie śmierci Aelreda i związane z tym czynności pośmiertne (,po co są fakty?”) są tu widziane oczyma braci, którzy w tym uczestniczyli. A wobec wielkiej wagi tej śmierci, bo dotyczyła wyjątkowego w ich mniemaniu opata, obiektywnie wygląda przesadzona, choć oddana adekwatnie do ich odczuć prawidłami retoryki (,musisz mi wybaczyć, jeżeli wyolbrzymiam to, co jest nieporównywalne, jak na to zasługuje, poprzez zastosowanie dozwolonej hiperboli”). Sama retoryka staje się tu jednocześnie środkiem wyrażenia niewyrażalnego poziomu Bożego $^{46}$. Jako hagiograficzne tło (exemplum) posłużył tu opis jaśniejącego ciała zmarłego św. Marcina z Tours. I to jest istota problemu w opisie śmierci Aelreda autorstwa Waltera Daniela.

Dla lepszego zrozumienia tego, trzeba przypomnieć, że autor był bardzo blisko związany ze zmarłym opatem i chyba najbardziej kompetentnym zarówno z racji wykształcenia, jak i zażyłości, by spisać jego hagiograficzną lamentację, i to zaraz po jego śmierci. To miało swoje znaczenie, bowiem wszystko było świeże w jego umyśle tak, że mógł wyrazić językiem retoryki to, co się kryło w jego sercu i w sercach wielu braci, którzy boleli po stracie swego ukochanego mistrza. Lepiej atmosferę tej straty oddał T.J. Heffernan, który zauważa, że Aelred był dla całej wspólnoty niejako symbolem odchodzącej generacji pierwszych wielkich fundatorów cysterskich, a już w ogóle pierwszym cystersem w Northumberlandii. Wraz z jego śmiercią kończyła się pewna ważna epoka, więc ta śmierć nabierała szczególnego i podniosłego znaczenia; była pewnym niezapomnianym i jedynym w swoim rodzaju wydarzeniem w ich życiu, które już nigdy miało się nie powtórzyć ${ }^{47}$. Na tym tle, rzeczywistością śmierci Aelreda

artificiose operator. Hic est illud ethnici dicentis: cuius ore sermon melle dulcior profluebat. Et in literis nostris: aquilis velociores leonibus forciores. Illudque in vita beati Martini: vitro purior lacte candidior [...]. Note iste non sunt notabiles, immo plane commendabiles, res magnas commendantes et stultos reprehensores irritantes. Quid enim? Aelredi corpus num mihi non luxit cum lavaretur defunctum? Vere lux nobis omnibus qui affuimus. At quomodo? Plus multo quam si carbunculus affuisset. Quod etiam super odorem thuris redolebat, sic nobis visum est, sic sensimum omnes. Nec mirum. Nunquam enim antea in vita sua carnem sic candidam gessit pulcher ille et decorus quomodo quando iacebat defunctus. Dico sine scupulo mendacii, nunquam ego tam candidam carnem vidi alterius cuiuslibet vivi vel defuncti. Ignoscite ergo michi quod rem incomparabilitem licita superlacione merito magnificavi. Aliquin auctores eloquentie stoliditatem vestram publica redargucione dampnabunt".

${ }^{46}$ Por. T.J. Heffernan, Sacred biography. Saints and their biographers in the Middle Ages, New York - Oxford 1988, 111-113.

47 Dobrze atmosferę tę oddają słowa Daniela (Vita Ailredi 1, ed. Powicke, s. 1) na samym początku Żywota: „Nasz ojciec umarł; zniknął z naszego świata jak jutrzenka i wiele serc tęskni za tym, by to światło zalało swym blaskiem pamięć następnych pokoleń, a nawet tych, którzy jeszcze żyją, dla których świecił w cały swym splendorze" (Pater noster obiit et quasi lux matutina euanuit e 
dla Daniela było również to, jak on ją przeżywał w sercu wraz z całą wspólnotą w obliczu tak niepowtarzalnej chwili, którą właśnie opisał. W tej perspektywie tradycyjne elementy hagiograficzne nabierają znaczenia przeżywanej rzeczywistości, wyrażonej językiem retorycznej symboliki, który jedyny jest w stanie oddać to, co kryło wtedy serce ${ }^{48}$. W tym samym tonie należy zapewne odczytywać wcześniejszą wzmiankę o chwalebnej wizji Aelreda, jaką otrzymał przed jego śmiercią nieznany z imienia współbrat.

Powyższą ideę miało potwierdzać teologiczne przyrównanie śmierci Aelreda do śmierci Jezusa Chrystusa na krzyżu oraz ukamienowania św. Szczepana, pierwszego męczennika. I nie chodziło tu tylko o przywołanie swoistego paradygmatu (ikony) umierania męczenników i ich oddania się Bogu w mistycznym zjednoczeniu z Chrystusem (Christi redux). Kluczem było dobranie słów z Ewangelii św. Łukasza i Dziejów Apostolskich, jakie wspomniane postaci miały wypowiedzieć w chwili swej śmierci i jakie miał powtórzyć opat przed swoim zgonem: „W ręce twoje Panie oddaję ducha mego” (Łk 23, 46; Dz 7, 59). Heffernan, umieszczając je na szerszym tle biblijnym (Ps 30,6; Gen 2,7), doszukuje się tu głębszego wymiaru teologicznego, jaki Daniel mógł chcieć przekazać swoim czytelnikom. Chciał widzieć Aelreda w roli templum Dei, w którym był obecny Duch Boży, zawsze kierujący jego świętym życiem, a szczególnie obecny w momencie śmierci. Chodzi o tego samego Ducha Boga, o stwórcze „Tchnienie życia” (spiraculum vitae), które dało początek całemu universum. Właśnie to „Tchnienie życia” było motorem świętego pielgrzymowania Aelreda i teraz zamieszkiwało w jego ciele ${ }^{49}$. I to było to, co nadawało wyjątkowości chwili jego śmierci: mnisi z Rievaulx byli świadkami śmierci kogoś wyjątkowego, świętego, w którym prawdziwie zamieszkiwał Duch Boży i który teraz umierał w chwale, czego znakiem było jaśniejące blaskiem jego ciało, na wzór św. Marcina z Tours.

\title{
THE DEATH OF AELRED OF RIEVAULX - BETWEEN THEORY AND REALITY
}

\author{
(Summary)
}

This article describes the death of the famous medieval abbot, Aelred, from the Cistercian abbey of Rievaulx (England, Yorkshire) (1110-1167). Walter Daniel of

terra nostra et multorum animo insidet ut radius tanti luminis refundatur ad memoriam et illuminacionem futuorum); szerzej na ten temat por. Heffernan, Sacred biography, s. 15, 72-73 i 107-109; Dutton, Introduction, s. 7-8 i 49-50.

${ }^{48}$ Por. Heffernan, Sacred biography, s. 109-113.

49 Por. tamże, s. 73 i 83-87. 
Rievaulx, Aelred's secretary and caretaker, was the only person who wrote about his death. Daniel was a very skillful monk, whose description of Aelred's death constituted a last part of his writings about Aelred's life (Vita Aelredi). The work was written soon after the death of the abbot, in hagiographical genre, typical to a monastic environment responding to definite circumstances which concerned some challenge. In response to accusations made against the abbot by a monk, Daniel wanted to confirm the holiness of Aelred by presenting him as a saint, in a hagiographical style, while describing his overly ambitious and strong lay lifestyle. Aelred's lifestyle during his long management of the abbacy (1147-1167), involved business trips pertaining to the matters of the church and state. In his writing however, Daniel did not concentrate on public activities of the abbot, but rather, he emphasized the abbot's wisdom, humility, patience, love and spiritual strength, and did so because those were the elements which constituted holiness in the Cistercian understanding, at that point in history. Daniel achieved the portrayal of Aelred as a saint, by discussing the abbot's life and relations to these elements, as well as by, underpinning them with numerous miracles Daniel truly believed that the abbot was a saint.

The holy life was crowned by the holy death, which expressed the monastic model of ,good death". As such, it contained not only the reality of death of the person with all social and traditional (religious) richness, but also miraculous hagiographical elements: prophecy of his own death, shining of the face and whole body of the dead man, and miracles on his grave. All these elements were drawn from the exemplary description of the death of St. Martin by Sulpicius Sever. Its goal was to confirm from above, the holiness of the described person. In his description of the death of Aelred, Walter Daniel follows this model of good death exactly.

But in this case his holiness was called into question by two prelates. Walter answered them later in his letter to certain Maurice (of Kirkham?), defending his point of view of Aelred giving a rare explanation of the application of the hagiographical elements. This is the subject of this paper, which is divided and explained in three parts: 1. The course of the death of Aelred (according to the model); 2 . Hagiographical elements of the description of the death of Aelred; 3. Interpretation of description of Aelredian death by Walter Daniel. 